\title{
EXPERIMENTAL INVESTIGATION OF MICROSTRUCTURE AND MECHANICAL PROPERTIES OF TIG WELDED ALUMINIUM ALLOYS.
}

\author{
R.R. Balasubramanian ${ }^{1 *}$, P. Vijayasarathi ${ }^{2}$, S. Kannan ${ }^{3}$, Dr.T. Venkatamuni ${ }^{4}$ \\ *I (III-year, students / Mechanical Engg., Jeppiaar institute of Technology, Kunnam, Chennai) \\ 2,3 (Asst.Professor/Mechanical Engg., Jeppiaar institute of Technology, Kunnam, Chennai) \\ ${ }^{4}$ (Professor/Mechanical Engg., Jeppiaar institute of Technology, Kunnam, Chennai) \\ *E-mail address: vijayasarathiprabakaran@gmail.com
}

*Corresponding Author: -

E-mail address: vijayasarathiprabakaran@gmail.com

\begin{abstract}
: -
Aluminium and its alloys are used in fabrication because of their low weight, good corrosion resistance and weldability. Pure aluminium is soft and therefore not suitable for structures, which require strength. The Present investigation aims to compare the mechanical properties of non-heat treatable Aluminium alloy AA5083 and heat treatable. Aluminium alloy AA7020 using Tungsten Inert Gas welding. 5556A filler were used to weld AA7020 alloy and 5183A filler for AA5083 alloy. Effect of pulsing mode over conventional mode of GTA process were also investigated for AA5083 alloy. In this work, gas tungsten arc welding process has been selected because it is low heat input process. Low heat input process has selected because AA7020 and AA5083 were low melting point material. The alternating current (AC) power source has been selected because of better cleaning action and high heat concentration on the materials can be avoided. Mechanical testing like tensile test, impact test, bend and hardness test have been critically analysed and the properties were summarized and correlating with microstructure and SEM fractographs.
\end{abstract}

Keywords: - Aluminium alloy, TIG welding, Microstructure, Mechanical properties. 


\section{INTRODUCTION:}

TIG welding was demonstrated first by Russell Meredith in 1930 during Second World War for welding aluminium and magnesium in aircraft industry [1].Among aluminum alloys, 5086-H32 (AlMg4), commonly used in defense, shipbuilding, automotive, railway, aviation and aerospace industries, is a representative non-age-harden able Al-Mg alloy that possesses an attractive combination of properties such as light weight, moderate high strength, good corrosion resistance, workability, and proven weld ability, good electrical and thermal conductivity [2-7]. The weld quality was strongly characterized by weld bead geometry because the weld pool geometry plays an important role in determining mechanical properties of weld [8-10].

Maximum quality can be achieved with control of welding parameters and material used must be cleaned [11]. The weld bead geometry of weld repaired aluminum alloy was similar as cast aluminum alloy in appearance but different in microstructure [12]. If welding speed decreases beyond an optimum value, depth of penetration decreases due to the pressure of electric arc on weld pool [13]. Less depth of penetration was obtained for low gun angle because of less pre-heating of base metal [14].

\section{Experimental}

The materials used for the present investigation are heat treatable Aluminium alloy of grade AA7020 of 5.5mm thickness and non-heat treatable Aluminium alloy of grade AA5083 of $6.25 \mathrm{~mm}$ thickness. The presence chapter details with the material required, their chemical composition and important mechanical properties, welding process used and their welding parameters. Specimen preparation for tensile testing, impact testing and bend testing and also for metallographic evaluations. Mechanical properties include tensile strength, angle of bend, toughness, hardness and these are detail in this chapter. The result of the chemical analysis of base metal and filler are given in the weight percentage of various elements of AA7020 and AA5083 alloy and filler wire are given in tables.

Table.1.Chemical composition of AA7020 alloy in weight percentage

\begin{tabular}{|r|c|c|c|c|c|c|c|c|}
\hline ELEMENT & $\mathbf{Z n}$ & $\mathbf{M g}$ & $\mathbf{M n}$ & $\mathbf{C r}$ & $\mathbf{S i}$ & $\mathbf{C u}$ & $\mathbf{Z i}$ & $\mathbf{A l}$ \\
\hline SPECIFIED & $4.0-5.0$ & $1.0-1.4$ & $\begin{array}{c}0.05- \\
0.50\end{array}$ & $\begin{array}{c}0.1- \\
0.35\end{array}$ & $<=0.35$ & $<=0.2$ & $\begin{array}{c}0.08- \\
\text { BAL }\end{array}$ & \\
\hline ANALYSED & 4.07 & 1.06 & 0.26 & 0.12 & 0.2 & 0.04 & 0.09 & $\mathrm{BAL}$ \\
\hline
\end{tabular}

Table.2. Chemical composition of AA5083 alloy in weight percentage

\begin{tabular}{|c|c|c|c|c|c|c|c|c|}
\hline ELEMENT & $\mathbf{S i}$ & $\mathbf{C u}$ & $\mathbf{M n}$ & $\mathbf{M g}$ & $\mathbf{C r}$ & $\mathbf{Z n}$ & $\mathbf{T i}$ & $\mathbf{A l}$ \\
\hline SPECIFIED & 0.40 & 0.40 & $0.40-$ & $4.0-$ & $0.05-$ & 0.25 & 0.15 & BAL \\
& & & 1.0 & 4.9 & 0.25 & & & \\
\hline ANALYSED & 0.23 & 0.15 & 0.84 & 3.84 & 0.08 & 0.10 & 0.08 & BAL \\
\hline
\end{tabular}

Table.3. Chemical composition of 5556 filler in weight percentage

\begin{tabular}{|c|c|c|c|c|c|c|c|}
\hline ELEMENT & $\mathbf{S i}$ & $\mathbf{C u}$ & $\mathbf{M n}$ & $\mathbf{M g}$ & $\mathbf{C r}$ & $\mathbf{Z n}$ & $\mathbf{A l}$ \\
\hline SPECIFIED & 0.25 & 0.10 & $0.5-1.0$ & $4.3-5.2$ & $\begin{array}{c}0.05- \\
0.25\end{array}$ & 0.25 & 0.25 \\
\hline
\end{tabular}

Table.4. Chemical composition of 5183 filler in weight percentage

\begin{tabular}{|c|c|c|c|c|c|c|c|c|}
\hline ELEMENT & $\mathbf{S i}$ & $\mathbf{C u}$ & $\mathbf{M n}$ & $\mathbf{M g}$ & $\mathbf{C r}$ & $\mathbf{Z n}$ & $\mathbf{T i}$ & Al \\
\hline SPECIFIED & 0.40 & 0.40 & $\begin{array}{c}0.05- \\
1.0\end{array}$ & $4.3-5.2$ & $\begin{array}{c}0.05- \\
0.25\end{array}$ & 0.25 & 0.25 & $\mathrm{BAL}$ \\
& & & & & \\
\hline
\end{tabular}

\subsection{Welding process:}

Plates were cut into coupons of dimensions $175 \times 125 \mathrm{~mm}$ for butt joint welding. Edge preparation was done in accordance with AWS-standard as V-groove of 60 included angle with depth of $4.7 \mathrm{~mm}$. Fixtures used for welding was equipped with special copper chilled bars to chill the heat- affected bone on both sides of weld. Oxides on the surface of plates in joint area are removes with scrapper or stainless steel wire. Just prior to welding test coupons surface were cleaned thoroughly with acetone in order to obtain a surface free from oil, grease and paint Welds were made using conventional gas tungsten arc welding process for welding AA5083, AA70250 alloys. Pulse gas tungsten arc welding process were also used to weld AA5083 alloys to study the effect of pulsing mode. Non-treatable Al-5\%mg alloy wire of $1.2 \mathrm{~mm}$ diameter AA, and $1.6 \mathrm{~mm}$ diameter AA5183 were used as filler. Pure argon with $99.996 \%$ purity is used as the shielding gas with flow rates ranging from 15 to 18 litres / $\mathrm{min}$. The regulators are provided in the cylinder whose main function is to reduce the cylinder. Gas pressure from $100 \mathrm{kgf} / \mathrm{cm}^{2}$ to the working pressure of 1 to $2 \mathrm{kgf} / \mathrm{cm}^{2}$. During the experiment the working pressure is set at $1 \mathrm{kgf} / \mathrm{cm}^{2}$.

\subsection{Welding parameteres:}

The parameters in table were obtained after experiencing with different parameters setting to obtain quality weld. The welding was carried out with a temporary backing that was removed after welding

Table.5. Welding for pulsed GTA processTable.6. Welding for Conventional GTA process 


\begin{tabular}{|l|l|}
\hline Voltage & $\begin{array}{l}22-24 \\
\text { volts }\end{array}$ \\
\hline Peak current & $250 \mathrm{Amps}$ \\
\hline Base current & $125 \mathrm{Amps}$ \\
\hline Travel supply & 644 \\
& $\mathrm{~mm} / \mathrm{min}$ \\
\hline Gas flow rate & $15-18$ \\
& lit/min \\
\hline
\end{tabular}

\begin{tabular}{|l|l|}
\hline Voltage & $22-24$ volts \\
\hline Welding current & $200 \mathrm{Amps}$ \\
\hline Travel speed & $30(\mathrm{~cm} \cdot \mathrm{min}-$ \\
& $1)$ \\
\hline Power supply & $\mathrm{AC}+5$ \\
\hline Frequency & $50 \mathrm{HB}$ \\
\hline Argon flow rate & $\begin{array}{l}15-18 \\
\text { lit } / \mathrm{min}\end{array}$ \\
\hline
\end{tabular}

\subsection{Non-destructive testing:}

Non-destructive examinations [LPT and RT] were carried out on the coupons both in as received conditions and after welding. Results shows that no flows were found and their quality were just acceptable as per code. In X-ray radiography, $\mathrm{X}$-ray source was operated at $140 \mathrm{KW}$ and $10 \mathrm{MA}$ wire parameters were employed to determine the sensitivity of the radiographs

\subsection{Mechanical testing:}

2.4.1. Tensile testing

To identify the weakest portion of the welded joint transverse tensile test was carried out the reduced section of the specimen contained base metal affected zone (HAZ) and weld metal. Samples for tensile tests were machined as per AWS B4.0.98 reduced transverse rectangular tension test specimen in shown in fig.

\section{Transverse rectangular tensile specimen (AWS B 4.0-98)}

\begin{tabular}{|c|c|}
\hline $\mathbf{T}$ & $\mathbf{W}$ \\
\hline$<1 \mathrm{INCH}$ & $1.50 \pm 0.01$ \\
\hline$\geq 1 \mathrm{INCH}$ & $1.00 \pm 0.01$ \\
\hline
\end{tabular}

\section{NOTE:}

For testing of tear and breaks near shoulder dimensions of "c" shall not greater than 1 to $1 / 3$ times the width of the reduced sections (i.e) W

\subsubsection{Impact testing:}

Impact toughness values are used in specifying acceptance standards impact specimens were machined from the plate according to ASTM standard weld metal impact properties were assessed at ambient temperature with a charpoy. Impact testing machine specimen for substandard charpy impact testing for weld shown in fig (all dimensions are in $\mathrm{mm}$ )

\subsubsection{Bend test:}

Aim of need test is to access ductility or absence of defects on the surface of the joint itself. It can be root face and side bend here I did root bend test and face bend test samples for root bend and face bend test is shown in fig

\begin{tabular}{|c|c|}
\hline $\mathrm{T}$ & $\mathrm{T}$ \\
\hline$<3 / 8 \mathrm{INCH}$ & $\mathrm{t}$ \\
\hline$\geq 3 / 8$ inch & $3 / 8 \mathrm{inch}$ \\
\hline
\end{tabular}

\subsection{Metallography studies:}

Microstructure of the weldment were studied with light optical microscope after preparing the metallographic samples in conventional manner Keller's reagent consisting of $10 \mathrm{ml}$ of conc. sulphuric acid, $5 \mathrm{ml}$ of hydro fluoric acid and $85 \mathrm{ml}$ of water was used to reveal the micro structural details

\subsection{Macro-analysis:}

For etching weld metal in tensile test, impact test, bend test, specimen following composition of macro etchant is used. This solution is tube used at room temperature and etching is accomplished by either swabbing or immersing the specimen
1. Conc.hcl
$15 \mathrm{ml}$,
2. $\mathrm{HF} 48 \%-10 \mathrm{ml}$,
3. Water
$85 \mathrm{ml}$

\section{Results and Discussion:}

2.1. Mechanical properties:

2.2. Mechanical properties of AA7020 and AA5083 are given in the table.7and table. 8 
Table.7. Mechanical properties of AA7020

\begin{tabular}{|c|c|}
\hline Yield strength & $335 \mathrm{MPa}$ \\
\hline Ultimate tensile strength & $380 \mathrm{MPa}$ \\
\hline Elongation percentage & 13 \\
\hline Shear stress & $230 \mathrm{mpa}$ \\
\hline Brinell hardness & $130 \mathrm{HB}$ \\
\hline Vickers hardness & $125 \mathrm{HV}$ \\
\hline
\end{tabular}

Table.8 Mechanical properties of AA5083

\begin{tabular}{|c|c|}
\hline Yield strength & $228 \mathrm{MPa}$ \\
\hline Ultimate tensile strength & $317 \mathrm{MPa}$ \\
\hline Elongation percentage & 16 \\
\hline Shear stress & $180 \mathrm{MPa}$ \\
\hline Fatigue strength & $159 \mathrm{MPa}$ \\
\hline Brinell hardness & $79 \mathrm{HB}$ \\
\hline
\end{tabular}

\subsection{Tensile Test Result:}

The tensile properties i.e, the ultimate tensile strength and the position of the fracture of AA7020, AA5083 conventional TIG welding and AA5083 pulsed TIG welding process weld ment are tabulated in above table. The average values of ultimate tensile strength for AA7020, AA5083(C) and AA5083 (P) weld ments were found to be 375mpa, 266mpa, and $270 \mathrm{mpa}$ respectively which is above the recommended ultimate tensile strength values of 360mpa and 250mpa. Even though fracture occurred in the weld region its ultimate tensile strength is higher than the recommended value. This shows that the weld quality is good and the joint efficiency is high. As compared toAA5083, the AA5083 (P) weld ments has high ultimate tensile strength of $270 \mathrm{mpa}$ due to pulsing, refinement of grains take place

Table.9. Transverse Tensile Test Result

\begin{tabular}{|c|c|c|c|}
\hline Idfn & Material & $\begin{array}{c}\text { Ultimate tensile } \\
\text { strength(MPa) }\end{array}$ & Position of fracture \\
\hline 01 & 7020 & 404 & WELD \\
\hline 02 & 7020 & 347 & WELD \\
\hline 03 & 5083 & 260 & WELD \\
\hline 04 & 5083 & 271 & WELD \\
\hline 05 & $5083(\mathrm{p})$ & 270 & WELD \\
\hline
\end{tabular}

\section{Impact Test Result:}

The values obtained after concluding the impact test for both base metal and weld metal is shown in fig It is not surprising that the weld metal impact value of both AA7020 and AA5083 is lower than the base metal value. Because Al-Mg filler is non age harden able alloy and further solidified weld metal microstructure shows a continuous interdendritic phase rich in magnesium inAA7020 alloy. The effect of interdendritic structure is found more in AA5083.

Table.10.Impact Test Result

\begin{tabular}{|c|c|c|c|}
\hline Idfn & Material & Location of notch & Impact energy in joules \\
\hline 01 & 7020 & Center of base metal & 18 \\
\hline 02 & 7020 & Center of base metal & 18 \\
\hline 03 & 7020 & Center of base metal & 18 \\
\hline 04 & 5083 & Center of base metal & 18 \\
\hline 05 & 5083 & Center of base metal & 19 \\
\hline 13 & 7020 & Heat affected zone & 18 \\
\hline 11 & 7020 & Center of weld & 19 \\
\hline 12 & 7020 & Center of weld & 17 \\
\hline 21 & 5083 & Center of weld & 19 \\
\hline 22 & 5083 & Center of weld & \\
\hline
\end{tabular}




\subsection{Bend test:}

The results for both face bend and root bend test for AA7020 and AA5083 alloy are presented in above tables.A critical examination of the tested samples did reveal that there were no cracks or any other major defects on the outer and also at the inner surface of both the bend specimens. After bending to $180 \AA$ and this conforms to the guidelines given.

Table.11. Face Bend Test Result

\begin{tabular}{|c|c|c|c|}
\hline Idfn & Material & Description & Remarks \\
\hline 011 & 7020 & no open discontinuity & passed \\
\hline 021 & 5083 & no open discontinuity & passed \\
\hline 031 & $5083(\mathrm{P})$ & no open discontinuity & passed \\
\hline 014 & 7020 & no open discontinuity & passed \\
\hline 024 & 5083 & no open discontinuity & passed \\
\hline 032 & $5083(\mathrm{P})$ & no open discontinuity & passed \\
\hline
\end{tabular}

Table .12.Root Bend Test Result

\begin{tabular}{|c|c|c|c|}
\hline Idfn & Material & Description & Remarks \\
\hline 012 & 7020 & $38 \mathrm{~mm}$ open discontinuity observed & failed \\
\hline 013 & 7020 & no open discontinuity observed & passed \\
\hline 022 & 5083 & no open discontinuity observed & passed \\
\hline 023 & 5083 & no open discontinuity observed & passed \\
\hline
\end{tabular}

\subsection{Hardness measurements:}

The specimens used for the metallographic examinations were also used for hardness measurements that were done with zwick wickers hardness testing machine. Hardness values for $5 \mathrm{~kg} \mathrm{HV}$ were measured from the fusion line towards the base metal along the HAZ

Table .13. Hardness result (vicker hardness, $5 \mathrm{~kg}$ load) (a) 5083 (TIGW-P)

\begin{tabular}{|c|c|c|}
\hline S.NO & Location & $\begin{array}{c}\text { Hardness } \\
\text { value }\end{array}$ \\
\hline 1 & Weld & 67 \\
\hline 2 & Weld & 68 \\
\hline 3 & Weld & 66 \\
\hline 4 & HAZ & 78 \\
\hline 5 & HAZ & 77 \\
\hline 6 & HAZ & 79 \\
\hline 7 & Base & 83 \\
\hline 8 & Base & 80 \\
\hline 9 & Base & 82 \\
\hline
\end{tabular}

(b) 5083 (TIGW-C)

\begin{tabular}{|c|c|c|}
\hline S.NO & Location & $\begin{array}{c}\text { Hardness } \\
\text { value }\end{array}$ \\
\hline 1 & Weld & 73 \\
\hline 2 & Weld & 74 \\
\hline 3 & Weld & 45 \\
\hline 4 & HAZ & 74 \\
\hline 5 & HAZ & 72 \\
\hline 6 & HAZ & 72 \\
\hline 7 & Base & 83 \\
\hline 8 & Base & 80 \\
\hline 9 & Base & 82 \\
\hline
\end{tabular}

(c) $7020($ TIGW)

\begin{tabular}{|c|c|c|}
\hline S.NO & Location & $\begin{array}{c}\text { Hardness } \\
\text { value }\end{array}$ \\
\hline 1 & Weld & 128 \\
\hline 2 & Weld & 127 \\
\hline 3 & Weld & 128 \\
\hline 4 & haz & 133 \\
\hline 5 & haz & 134 \\
\hline 6 & haz & 133 \\
\hline 7 & Base & 140 \\
\hline 8 & Base & 137 \\
\hline 9 & Base & 137 \\
\hline
\end{tabular}

A hardness survey was made across weld metal, heat affected zone (HAZ) and base metal to study the effect of weld thermal cycles. The hardness values obtained from the survey are shown in above table. Since the filler used in non-age harden able and non-matching compositions with the base metal, weld metal hardened is different from and lower than the base metal. The base metal being in age condition, any thermal cycle could affect its hardness values because of over aging. But region within heat affected zone (HAZ) regain its hardness by natural aging.

\subsection{Microstructure of welded joint:}

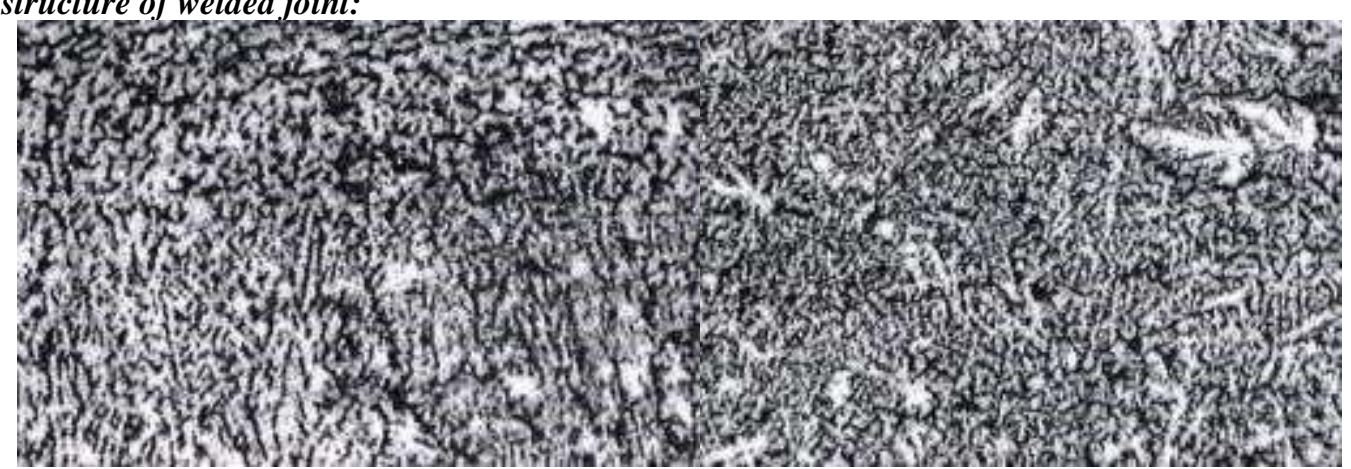




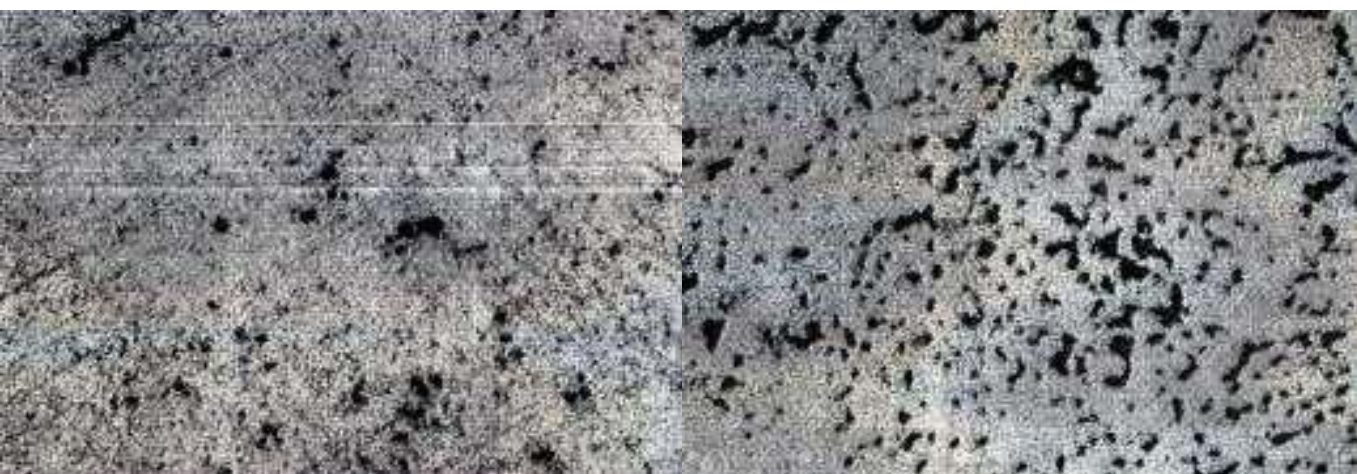

(c)AA5083 Base metal at 200x

(d)AA5083 (pulsed TIGW) HAZ at 200x

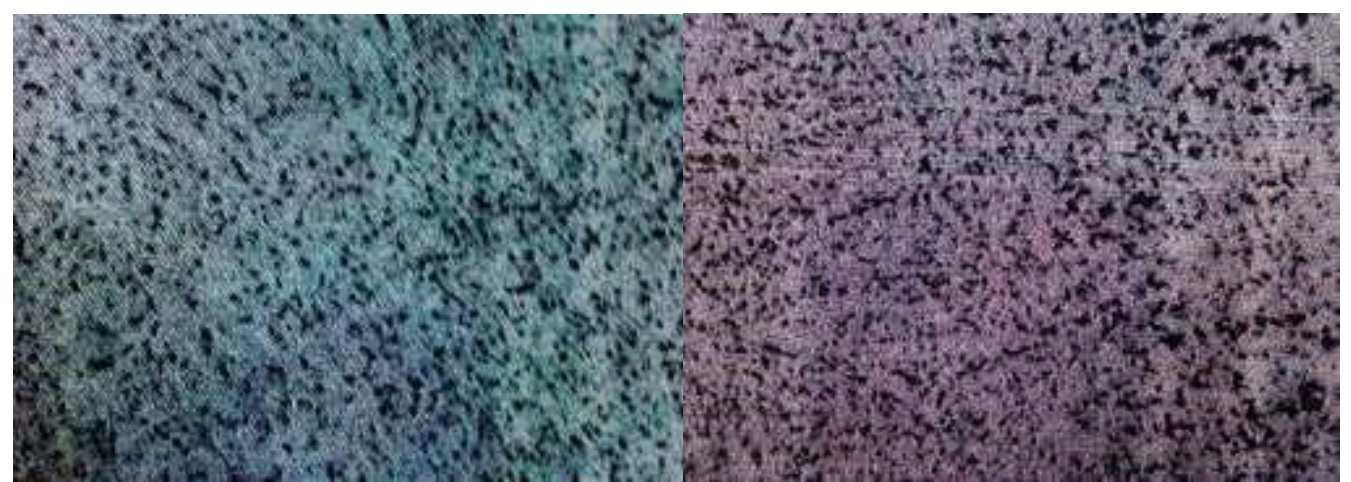

(e)AA5083(pulsed TIGW) weld at 100x

(f) AA7020 Base metal at 50x

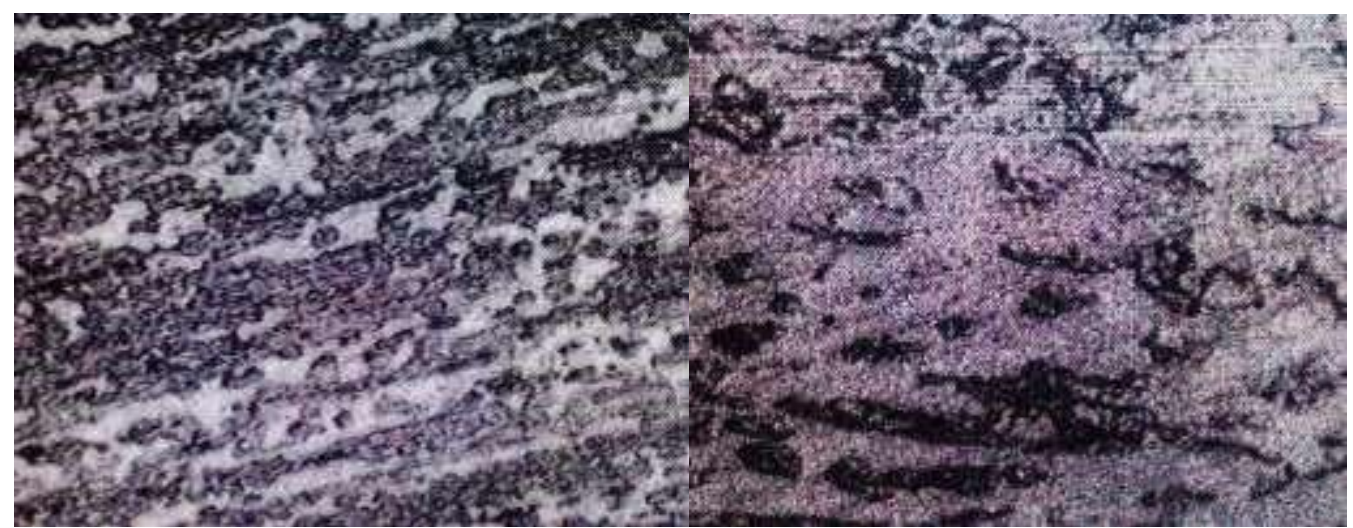

(g) AA7020 HAZ at $200 x$

(h) AA7020 weld at $100 x$

Fig.1.Microstructure of welded joint:

Weld metal (conventional TIG) of AA5083 is shown in micrograph reveal general structures of aluminium with Mg2A13 precipitates near the dendrite boundaries, forming the dark band. Weld metal interface of AA5083(conventional TIG) is shown in micrograph, which reveal fine and coarse dendrites of aluminium with much $\mathrm{Mg} 2 \mathrm{~A} 13$, precipitate near dendrite boundaries. Microstructure clearly reveals that there is a clear demarcation between fine dendrites and coarse dendrites developed during the first and second pass of welding operation. The base metal microstructure is shown in micrograph reveal particles of primary MnA16 in aluminium matrix. HAZ of AA5083 (pulsed TIG) is shown in micrograph, reveal coarse precipitates of $\mathrm{Mg} 2 \mathrm{~A} 13$ uniformly distributed in aluminium Matrix. Here dendrites of aluminium were absent in pulsing technique, fine precipitate is absorbed and its distribution is more or less uniform.

Base metal of AA7020 is shown in micrograph reveal dendrites of aluminium with much MgZn2 precipitate near dendrite boundaries forming the dark band. Weld metal microstructure of AA7020 is shown in micrograph clearly reveals particles of MgZn2 in aluminium matrix. Here the precipitates were over aged that leads to decreases in hardness. In HAZ, precipitates were accumulated instead of coarsening that leads to marginal increases in hardness value as compared to weld metal. This is clearly seen in micrograph. 


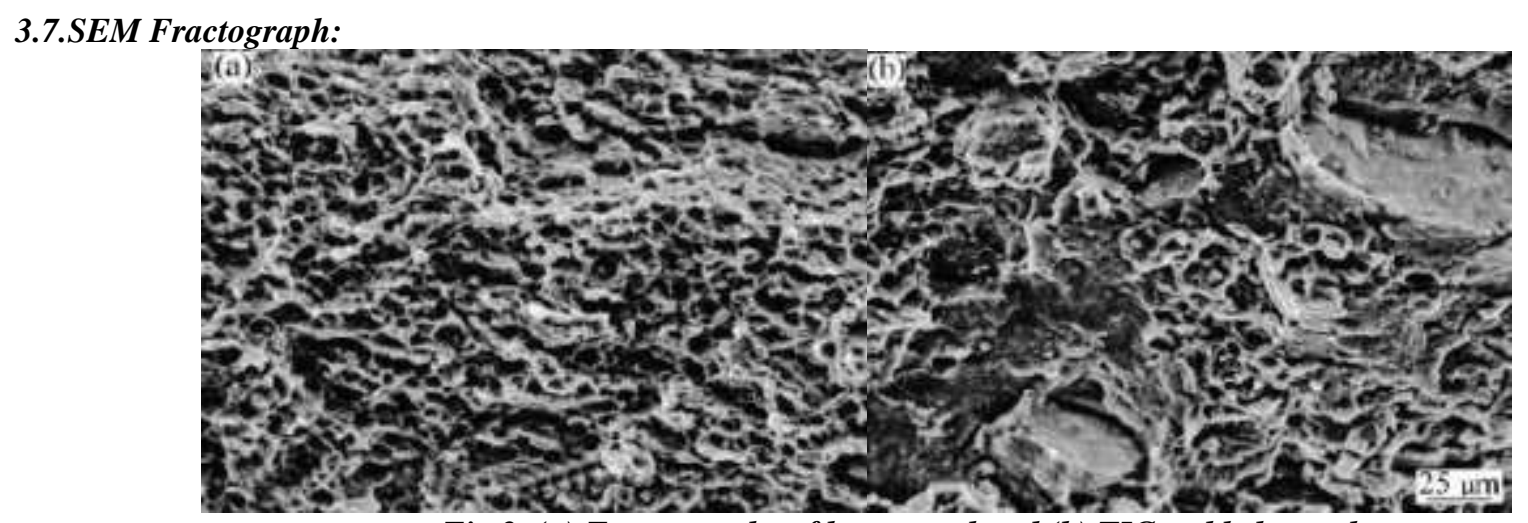

Fig.2. (a) Fractographs of base metal and (b) TIG welded sample

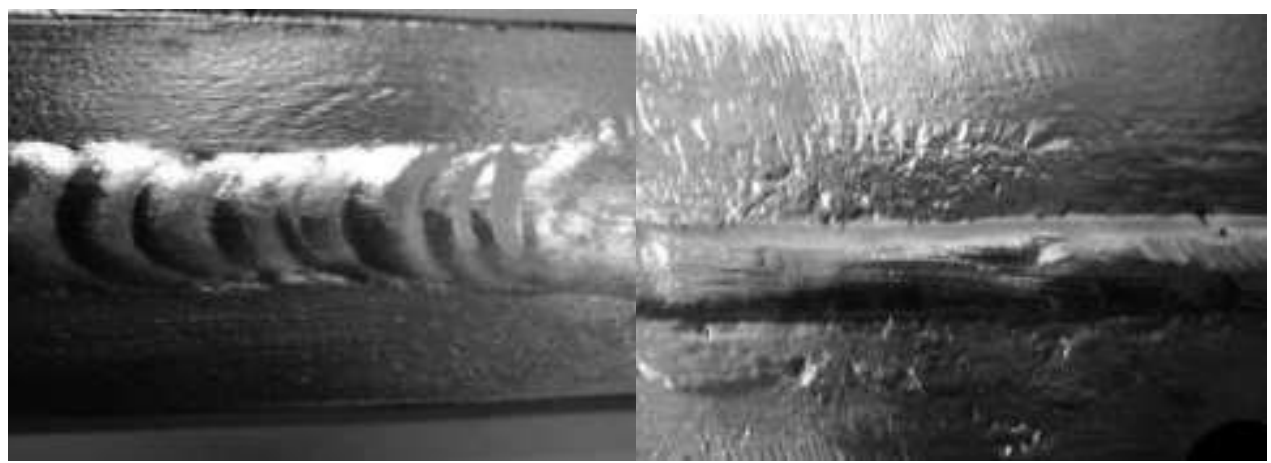

Fig.3.Macro-morphology of welded seam: (a) Front face; (b) Back face

The fine dimples can just be distinguished on the surfaces adjacent to the large dimples. Many alloy second phase particles are discernible, although some are so deep within the dimples as to be nearly invisible. SEM fractograph shows a similar array of dimples, most of which are of uniform size. SEM fractograph contains an array of dimples, showing a wide variation in sizes. SEM fractograph contains large dimples showing the inclusions that initiated them. Fine dimples that are too small to be resolved at this magnification exist among the large dimples. The dimples in the SEM fractograph show that the fracture is ductile fracture.

\section{Conclusion:}

- Tensile test reveals that AA7020 Aluminium alloy weld joint is having higher strength than AA5083 both conventional and pulsed TIG welded joints.

- Weld joints made from AA5083 Aluminium alloy is having higher ductility than AA7020 weld joints.

- When comparing the hardness values, AA7020 having higher hardness than AA5083 conventional and AA5083 pulsed weld joints.

- Though the strength and hardness are higher in AA7020 Aluminium alloy when compare to AA5083, it fails in bend test. So it reveals that AA7020 has poor ductility.

- From the above results AA5083 Aluminium Alloy weld joint (conventional) is having better mechanical and metallurgical properties.

\section{References}

[1] Gadewar, S., Swaminadhan, P. and Harkare, M. (2010), "Experimental investigations of weld characteristics for a Single pass TIG weldingwith Stainless steel”, Journal of Engineering and Technology, Vol.2, No.8, pp.3676-3686.

[2] ZHOU, C.-YANG, X.-LUANET, G.: Scripta Materialia,53, 2005, p. 1187.

[3] MATHERS, G.: The Welding of Aluminium and Its Alloys. Cambridge, Woodhead Publishing Limited 2002.

[4] ANDERSON, T.: Welding Journal, 81, 2002, p. 77.

[5] ANDERSON, T.: Welding Journal, 83, 2004, p. 28.

[6] JOHNSEN, M. R.: Welding Journal, 78, 1999, p. 35.

[7] KALLEE, S. W.-DA VENPORT, J.-NICHOLAS, E. D.: Welding Journal, 81, 2002, p. 47.

[8] Lee JI, Um KW. A prediction of welding process parameters by prediction of back-bead geometry. J Mater Process Technol, 2000.

[9] Raveendra J, Parmar RS. Mathematical models to predict weld bead geometry for flux cored arc welding. Met Construct, 1987.

[10] Khanna, O.P. (2006), “A text book of welding technology”, Dhanpat Rai PublicationsLtd., pp.3

[11] Minnick.and William, H. (1996), "Gas tungsten arc welding handbook", Tinley Park, Illinois: Goodheart-Willcox Company, pp.71-73.

[12] Li, L., Liu, Z. and Snow, M. (2006), "Effect of defects on fatigue strength of GTAW repaired cast aluminum alloy", pp.1s-6s. 
[13] Welding Handbook (4th edition) section 2, "Gas, arc and resistance welding processes", published by American Welding Society.

[14] Sudhakaran, R., Vel, M. and Sivasakthivel, P. (2012), "Optimization of process parameters to minimize angular distortion in gas tungsten arc welded stainless steel grade plates”, Journal of Engineering Science and Technology, Vol.7, No.2, pp.195-208. 